\title{
The Mechanism of Bicarbonate Reabsorption in the Proximal and Distal Tubules of the Kidney*
}

\author{
Floyd C. Rector, Jr., Norman W. Carter, and Donald W. Seldin with the \\ technical assistance of Allen C. NunN
}

(From the Department of Internal Medicine, the University of Texas Southwestern Medical School, Dallas, Texas)

Considerable evidence (1-6) has been adduced to support the hypothesis that the reabsorption of filtered $\mathrm{HCO}_{3}-$ by the kidney is mediated by a single mechanism, operative in both the proximal and distal portions of the nephron, which involves the secretion of cellular $\mathrm{H}^{+}$in exchange for luminal $\mathrm{Na}^{+}$. The secreted $\mathrm{H}^{+}$reacts with filtered $\mathrm{HCO}_{3}^{-}$to form $\mathrm{H}_{2} \mathrm{CO}_{3}$, which then decomposes to $\mathrm{CO}_{2}$ and $\mathrm{H}_{2} \mathrm{O}$.

Difficulties arise, however, when the details of the process are examined. In the steady state, the rate at which the $\mathrm{H}_{2} \mathrm{CO}_{3}$ is removed from the luminal fluid must equal the rate at which $\mathrm{H}^{+}$is secreted. Walser and Mudge (7) have estimated that for the uncatalyzed dehydration of $\mathrm{H}_{2} \mathrm{CO}_{3}$ to account for the observed rates of $\mathrm{HCO}_{3}{ }^{-}$reabsorption, the steady-state concentration of $\mathrm{H}_{2} \mathrm{CO}_{3}$ in luminal fluid must be at least tenfold greater than the concentration that would exist were $\mathrm{H}_{2} \mathrm{CO}_{3}$ in equilibrium with the $\mathrm{CO}_{2}$ tension of luminal fluid and plasma. As a result of the excess $\mathrm{H}_{2} \mathrm{CO}_{3}$, the steady-state $\mathrm{pH}$ would be approximately $1 \mathrm{pH} \mathrm{U}$ lower than would be predicted from the luminal concentration of $\mathrm{HCO}_{3}^{-}$ and the $\mathrm{CO}_{2}$ tension of plasma, assuming complete equilibration of luminal $\mathrm{H}_{2} \mathrm{CO}_{3}$ with plasma $\mathrm{CO}_{2}$. A marked disequilibrium $\mathrm{pH}^{1}$ would exist.

Two lines of evidence have been advanced to support the presence of a disequilibrium $\mathrm{pH}$ in the proximal tubule. Rector and Carter (8) perfused single proximal tubules with $\mathrm{NaHCO}_{3}$

* Submitted for publication July 27, 1964 ; accepted October 29, 1964.

Supported in part by a grant from the American Heart Association and in part by grants 5 TI AM-5028 and 5 TI HE-5469 from the National Institutes of Health.

1 The difference between the actual $\mathrm{pH}$, under conditions where $\mathrm{CO}_{2}$ and $\mathrm{H}_{2} \mathrm{CO}_{3}$ are not in equilibrium, and the calculated equilibrium $\mathrm{pH}$ will be termed "disequilibrium" $\mathrm{pH}$. and estimated the steady-state intraluminal $\mathrm{pH}$ from the change in color of various acid-base indicators. The $\mathrm{pH}$ was found to be about $1.5 \mathrm{U}$ lower than the predicted equilibrium $\mathrm{pH}$. However, since the color change could result from loss of dyes by either reabsorption or binding to cell proteins, the validity of these results may be questioned. Bank and Aynedjian (9) measured intratubular $\mathrm{pH}$ by aspirating tubular fluid into quinhydrone microelectrodes and comparing the readings while the electrode was still in the tubular lumen with the values obtained when the fluid was removed from the tubule and permitted to reach equilibrium. With this technique, they found the intratubular $\mathrm{pH}$ to be 2.0 to $2.5 \mathrm{pH} \mathrm{U}$ below the equilibrium $\mathrm{pH}$. These results, however, are open to the serious objection that a disequilibrium $\mathrm{pH}$ of this magnitude would require the generation of $\mathrm{H}_{2} \mathrm{CO}_{3}$ at a rate 10 to 50 times greater than is theoretically possible, as judged from the rate of $\mathrm{HCO}_{3}{ }^{-}$reabsorption.

The presence of a disequilibrium $\mathrm{pH}$, however, is not a necessary consequence of the hypothesis that $\mathrm{H}^{+}$secretion mediates $\mathrm{HCO}_{3}{ }^{-}$reabsorption. An equilibrium $\mathrm{pH}$ could obtain if $\mathrm{H}_{2} \mathrm{CO}_{3}$ were rapidly removed from the tubular urine by either of two mechanisms: 1) nonionic diffusion of $\mathrm{H}_{2} \mathrm{CO}_{3}$ out of the lumen (6); or 2) catalytic decomposition of $\mathrm{H}_{2} \mathrm{CO}_{3}$ to $\mathrm{CO}_{2}$ and $\mathrm{H}_{2} \mathrm{O}$, perhaps as a result of the luminal action of carbonic anhydrase, a possibility suggested by both Walser and Mudge (7) and Rector, Seldin, Roberts, and Smith (6).

Finally, it is possible that $\mathrm{HCO}_{3}{ }^{-}$reabsorption is accomplished by the direct removal of $\mathrm{HCO}_{3}{ }^{-}$ ions (10). Since excess $\mathrm{H}_{2} \mathrm{CO}_{3}$ would not be generated in the tubular fluid by this process, the steady-state intraluminal $\mathrm{pH}$ would equal the calculated equilibrium $\mathrm{pH}$. 
The present study constitutes an attempt to characterize the mechanism of $\mathrm{HCO}_{3}^{-}$reabsorption in proximal and distal tubules. By comparing the steady-state intraluminal $\mathrm{pH}$ (measured directly with $\mathrm{pH}$-sensitive glass microelectrodes) to the calculated equilibrium $\mathrm{pH}$, the presence or absence of a disequilibrium $\mathrm{pH}$ was ascertained. In the proximal tubule no disequilibrium $\mathrm{pH}$ was found under steady-state conditions of $\mathrm{NaHCO}_{3}$ infusion. However, when carbonic anhydrase was inhibited, a significant disequilibrium of $0.85 \mathrm{pH} \mathrm{U}$ was demonstrated. It was, therefore, concluded that $\mathrm{HCO}_{3}{ }^{-}$reabsorption in the proximal tubule was mediated by $\mathrm{H}^{+}$secretion, but the luminal action of carbonic anhydrase prevented $\mathrm{H}_{2} \mathrm{CO}_{3}$ from accumulating in the tubular fluid. In the distal tubule the steady-state $\mathrm{pH}$ during $\mathrm{NaHCO}_{3}$ infusion was 0.85 lower than the equilibrium $\mathrm{pH}$. This clearly indicated that $\mathrm{HCO}_{3}{ }^{-}$reabsorption in this segment was accomplished by $\mathrm{H}^{+}$secretion. The absence of carbonic anhydrase in the luminal membranes of distal tubular cells permitted $\mathrm{H}_{2} \mathrm{CO}_{3}$ to accumulate in the tubular fluid, thereby producing a disequilibrium $\mathrm{pH}$.

\section{Methods}

Male Sprague-Dawley rats, weighing 250 to $300 \mathrm{~g}$, were anesthetized by an intraperitoneal injection of sodium pentobarbital, tracheotomized, and placed on a heated animal board. The left kidney was exposed through a wide abdominal incision and placed in a small plastic cup firmly attached to the animal board. To prevent loss of $\mathrm{CO}_{2}$, the surface of the kidney was covered with silicone oil and equilibrated with $5 \% \quad \mathrm{CO}_{2}$. Silicone oil was used rather than mineral oil because it was found not to interfere with the $\mathrm{pH}$ sensitivity of the glass microelectrodes. The external jugular vein was cannulated with small polyethylene tubing for the infusion of drugs and solutions. Blood samples were collected from polyethylene tubing in the femoral artery. Urine was collected by placing a polyethylene cannula in the bladder.

In the first group of experiments the $\mathrm{pH}$ of intratubular fluid in normal, untreated rats was measured with glass $\mathrm{pH}$ electrodes and compared to the $\mathrm{pH}$ of tubular fluid aspirated into quinhydrone $\mathrm{pH}$ electrodes from other nephrons. In the second group of experiments, the rats were infused with $0.15 \mathrm{M} \mathrm{NaHCO}$ at the rate of 0.1 to $0.2 \mathrm{ml}$ per minute for at least 60 minutes. The intratubular $\mathrm{pH}$ was then measured by puncturing individual nephrons with a glass $\mathrm{pH}$ electrode and recording the $\mathrm{pH}$ for at least 30 seconds. Immediately thereafter fluid was collected from the same puncture site into a quin- hydrone electrode for the measurement of the concentration of $\mathrm{HCO}_{3}^{-}$in the tubular fluid. Simultaneously a sample of arterial blood was collected for the measurement of $\mathrm{pH}$ and $\mathrm{CO}_{2}$ content. In a third group of rats, also infused with $\mathrm{NaHCO}_{3}$, this procedure was repeated before and after the intravenous injection of 2 mg per $\mathrm{kg}$ body weight of the carbonic anhydrase inhibitor, 2-benzenesulfonamido-1,3,4-thiadiazole-5-sulfonamide (CL 11, 366). ${ }^{2}$ This inhibitor was used because Travis, Wiley, Nechay, and Maren (11) have shown that at the dose of $2 \mathrm{mg}$ per $\mathrm{kg}$ maximal renal effects are obtained without any appreciable red cell effects. Therefore, the plasma $\mathrm{PCO}_{2}$ does not rise as it does with acetazolamide. In a fourth group of rats, infused with $\mathrm{NaHCO}_{3}$, the $\mathrm{pH}$ measurements were performed before and after injection of $10 \mathrm{mg}$ of carbonic anhydrase ${ }^{3}$ intravenously. This amount of carbonic anhydrase resulted in high carbonic anhydrase activity in the urine when assayed by the method of Davis (12).

The tubular puncture site was localized by injecting the tubule with latex as previously described (13).

Measurement of intratubular $p H$. To measure intratubular $\mathrm{pH}$, microelectrodes with tip diameters less than $2 \mu$ and with the $\mathrm{pH}$ sensitivity limited to the terminal 15 to $20 \mu$ of the tip were prepared from Corning 015 pH-sensitive capillary glass tubing ( $1 \mathrm{~mm}$ o.d.) in the following manner. First, 6-cm lengths of capillary were insulated by applying a thin coat of Pemco no. TR-514-A glaze with a fine brush. The coated capillary tubes were air dried and then heated in an oven at $600^{\circ} \mathrm{C}$ for $10 \mathrm{~min}$ utes to fuse the glaze to the capillary surface. This procedure completely blocked the $\mathrm{pH}$ sensitivity of the capillary. Next the capillaries were heated in a Scientific Instruments pipette puller and pulled to a $1-$ to $2-\mu$ tip ; in this step $\mathrm{pH}$-sensitive glass was pulled from underneath the insulation to form the tip. By proper adjustment of the heat and strength of the pipette puller approximately 15 to $20 \mu$ of the tip was $\mathrm{pH}$ sensitive. The electrodes were filled with distilled $\mathrm{H}_{2} \mathrm{O}$ by heating under vacuum. After filling with $\mathrm{H}_{2} \mathrm{O}$ the electrode tips were closed by heating with a DeFonbrune microforge.

In some instances double-barrelled electrodes were prepared, one side being $\mathrm{pH}$ sensitive, the other serving as a reference electrode. A glazed $\mathrm{pH}$ capillary and a slightly larger capillary (1.5 mm o.d.) made from Corning 0129 lead glass were cemented together with epoxy cement. This double-barrelled capillary was then heated in the pipette puller until the glass was soft; the glass was twisted one full revolution, spiraling the two pieces of glass around one another; the pipette puller was then released, pulling the two capillaries into a single doublebarrelled tip. By using lead glass capillary slightly larger in diameter than the $\mathrm{pH}$-sensitive glass, the tip of the reference side pulled out further than the $\mathrm{pH}$ side. This resulted in the $\mathrm{pH}$ side being pulled closed, while the reference tip remained open. Both sides of the elec-

2 The authors are indebted to Dr. Thomas Maren for generously supplying the CL 11,366 .

${ }^{3}$ Nutritional Biochemical Corp., Cleveland, Ohio. 
trode were then filled with distilled $\mathrm{H}_{2} \mathrm{O}$ by heating under vacuum.

The process of pulling and closing the electrodes altered the glass so that the tip resistances were very high $\left(10^{11} \mathrm{ohms}\right)$ and the $\mathrm{pH}$ sensitivity was poor. However, by soaking the electrodes in distilled $\mathrm{H}_{2} \mathrm{O}$ at $4^{\circ} \mathrm{C}$ for at least 2 weeks the tip resistances fell to approximately $10^{\circ}$ ohms, and $\mathrm{pH}$ sensitivity was regained; this effect is presumably due to rehydration of the exposed glass tip.

It was found that the electrode tips dissolved within 1 to 3 days when filled with conventional reference solutions. This process, however, was much slower when the electrodes were filled with distilled $\mathrm{H}_{2} \mathrm{O}$. For this reason the electrodes were used with distilled $\mathrm{H}_{2} \mathrm{O}$ as the internal reference solution. Although distilled $\mathrm{H}_{2} \mathrm{O}$ ordinarily has a very low conductivity and hence is a poor reference solution, sufficient electrolyte was leached from the $\mathrm{pH}$ glass within 1 to 2 days to raise the conductivity of the water far above that of the glass, so that the $\mathrm{H}_{2} \mathrm{O}$ functioned as a perfectly satisfactory reference solution. The tip resistance and $\mathrm{pH}$ sensitivity of the electrodes filled with distilled $\mathrm{H}_{2} \mathrm{O}$ were the same as when filled with more conventional reference solutions.

Either the single electrode or the $\mathrm{pH}$ side of the double electrode was placed in a Teflon electrode holder filled with $2.5 \mathrm{M} \mathrm{KCl}-0.5 \mathrm{M} \mathrm{KNO}$; a $\mathrm{Ag}-\mathrm{AgCl}$ electrode in contact with the electrolyte solution in the holder was connected to the input of a Cary model 31 vibrating-reed electrometer with input impedance of $10^{14}$ ohms. The output of the electrometer was connected to a Leeds-Northrup recording potentiometer for a continuous record of all measurements. When single electrodes were used, a Beckman calomel electrode served as a reference. When the double electrodes were used, the distilled $\mathrm{H}_{2} \mathrm{O}$ in the reference side was displaced by threading small polyethylene tubing almost to the tip and injecting 2.5 M KCl-0.5 $\mathrm{M} \mathrm{KNO}_{3 .}{ }^{4} \mathrm{~A}$ 28-gauge Ag$\mathrm{AgCl}$ electrode was inserted into the reference side and sealed with picene cement. The electrode holder containing either a single or double-barrelled $\mathrm{pH}$ electrode was then mounted on the head of a DeFonbrune micromanipulator.

The $\mathrm{pH}$ sensitivity of each electrode was tested by

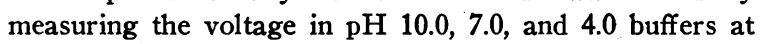
$37^{\circ} \mathrm{C}$. All electrodes reading less than $40 \mathrm{mv}$ per $\mathrm{pH} \mathrm{U}$ were discarded. Most of the electrodes read between 45 and $55 \mathrm{mv}$ per $\mathrm{pH} \mathrm{U}$, with a few approaching the theoretical value of $61 \mathrm{mv}$ per $\mathrm{pH} U$. In all of the acceptable electrodes voltage was linearly related to $\mathrm{pH}$ over a range from $\mathrm{pH} 4$ to $\mathrm{pH} 10$. The tip resistance of each electrode was determined from the voltage drop produced by switching a shunt resistor of known value between the input and reference sides of the circuit. Electrodes

4 Extensive preliminary testing showed that when the reference side was filled with $3 \mathrm{M} \mathrm{KCl}$, a significant number of the electrodes had variable tip potentials when placed in buffer solutions of different anionic composition (phosphate versus phthalate). This variation was obviated by using a mixture of $\mathrm{KCl}$ and $\mathrm{KNO}_{3}$. with tip resistances greater than $10^{10}$ ohms were discarded because of their slow response time and susceptibility to interference from static charge. Even with tip resistances less than $5 \times 10^{\circ}$ ohms, however, it was necessary that the readings be performed inside a Faraday cage; it was also necessary that the operator, who was inside the cage, wear grounded shoes and a cotton surgical scrub suit to reduce static electricity.

Several different systems were devised to measure the length of the $\mathrm{pH}$-sensitive portion of the tip. These were usually unsatisfactory and resulted in a high rate of electrode breakage. Eventually it was found that the renal tubule itself was the best system in which to test the insulation of the electrode. When testing the singlebarrelled electrodes, the reference calomel electrode was placed in a small beaker of isotonic saline into which the clipped end of the rat's tail was inserted; the potential difference between this electrode and a second reference electrode placed on the surface of the kidney was zero. Three small cups containing $\mathrm{pH}$ buffer standards in $3 \%$ agar ( $\mathrm{pH} 4.0,6.75,7.32$ ) were placed in the peritoneal cavity of the rat; each cup was in electrical contact with the peritoneal surface through an opening in the bottom of the cup. By placing these cups in the peritoneal cavity the standard buffers were maintained at the body temperature of the rat. The $\mathrm{pH}$ electrodes were standardized by reading the voltage obtained in each of these three buffers.

After calibrating the electrode, a tubule was punctured by a double-barrelled injection pipette. One side of this pipette was filled with silicone oil and the other with an isotonic buffer solution. The tubule was filled with oil and then punctured with the $\mathrm{pH}$ electrode. Well-insulated electrodes read as an open circuit when the electrode tip was in the oil. The oil drop was then split, and the buffer solution was perfused past the electrode tip; the occasional electrode that did not read within 0.1 to $0.2 \mathrm{pH} \mathrm{U}$ of the known $\mathrm{pH}$ of the buffer was discarded. As a final test, a second buffer, differing in $\mathrm{pH}$ from the intratubular buffer, was layered over the surface of the kidney; if this procedure caused a permanent shift in reading greater than $0.1 \mathrm{pH} \mathrm{U}$ the electrode was discarded.

Once an electrode had met all the above criteria it was considered satisfactory for the measurement of intratubular $\mathrm{pH}$. The intratubular $\mathrm{pH}$ was determined by puncturing single nephrons and recording the voltage for 30 to 180 seconds. The calibration of the electrode was checked in the $\mathrm{pH} 7.32$ buffer before and after each measurement of intratubular $\mathrm{pH}$. If for any reason the $\mathrm{pH}$ reading in the buffer was different after the tubular puncture from before, the measurement of tubular $\mathrm{pH}$ was discarded, and the entire system was recalibrated.

Theoretically the transtubular potential difference should influence the measurement of intratubular $\mathrm{pH}$. Ideally the reference electrode should be inside the tubule to avoid this source of error. On a practical level, however, it was found that in the proximal convoluted tubule there was no sustained transtubular potential difference when punctured with a $2-\mu$ electrode. There- 
fore, the placement of the reference electrode had no influence on the measured intratubular $\mathrm{pH}$. Since the single-barrelled electrodes were much easier to produce and use than the double-barrelled electrodes, the single electrodes were used for most of the proximal measurements. In contrast, the distal convoluted tubule was capable of sustaining a high potential difference $(-40$ to $-75 \mathrm{mv}$ ) when punctured with the $\mathrm{pH}$ electrodes. For this reason, it was not possible to obtain valid measurements with the single-barrelled electrodes, and consequently, double-barrelled electrodes were used for all measurements in the distal tubule.

When using the double-barrelled electrodes, the transtubular potential difference was measured by connecting the reference side of the electrode to the input of the electrometer and reading against a Beckman calomel electrode. The reference level against which to read the tubular potential was obtained by first measuring the potential when the electrode tip was placed in the small drops of transudate fluid that collected between the surface of the kidney and the covering layer of oil.

Measurement of $\mathrm{HCO}_{3}{ }^{-}$concentration in tubular fluid. Quinhydrone microelectrodes (14), filled with mineral oil equilibrated with $5 \% \mathrm{CO}_{2}$, were used to measure the $\mathrm{pH}$ of aspirated samples of tubular fluid, as previously described (15). Since the $\mathrm{pH}$ of the samples was measured at a constant $\mathrm{PCO}_{2}$ of approximately $40 \mathrm{~mm} \mathrm{Hg}$ in the quinhydrone electrode rather than at the actual $\mathrm{PCO}_{2}$ of plasma, the measured value was not the true $\mathrm{pH}$ of the tubular fluid, but represented instead a measure of the $\mathrm{HCO}_{3}^{-}$concentration in the tubular fluid (16). The concentration of $\mathrm{HCO}_{3}{ }^{-}$in tubular fluid, $\left[\mathrm{HCO}_{3}^{-}\right]_{\mathrm{Tr}}$, was calculated from the quinhydrone $\mathrm{pH}$ and the known $\mathrm{PCO}_{2}$ of the mineral oil in the electrode by the HendersonHasselbalch equation with a $\mathrm{pK}$ of 6.1 and a $\mathrm{CO}_{2}$ conversion factor of $.0301 \mathrm{mmole}$ per $\mathrm{mm} \mathrm{Hg}$.

To establish whether the samples equilibrated with the $5 \% \mathrm{CO}_{2}$ in the mineral oil, the following procedure was performed. Two $\mathrm{HCO}_{3}^{-}$standards $(25$ and $50 \mathrm{mEq}$ per L) were equilibrated with either 5,10 , or $20 \% \mathrm{CO}_{2}$ and aspirated into the quinhydrone electrodes. The $\mathrm{pH}$ of each equilibrated solution, when measured in a Beckman anaerobic glass electrode, accurately reflected the marked differences in $\mathrm{CO}_{2}$ tension (Table $\mathrm{I}$ ). The quinhydrone $\mathrm{pH}$ of the equilibrated solutions, however, was dependent upon the size of the aspirated sample. As shown in Table I, when the quinhydrone electrode was filled with $0.01 \mu 1$, or less, of the $\mathrm{HCO}_{3}{ }^{-}$solutions, the $\mathrm{pH}$ of a given standard read the same irrespective of the percentage of $\mathrm{CO}_{2}$ with which it was originally equilibrated; the actual $\mathrm{pH}$ was that which would be predicted if the solution were in equilibrium with the $\mathrm{CO}_{2}$ tension of the mineral oil. In contrast, when the quinhydrone electrode was filled with $0.05 \mu \mathrm{l}$ or more of the solution, the $\mathrm{pH}$ of a given standard was similar to the $\mathrm{pH}$ measured in the Beckman electrode and varied as predicted from the original $\mathrm{CO}_{2}$ tension of the solution; the $\mathrm{pH}$ was relatively stable, but over a 30 - to 45 -minute period would drift very slowly in an alkaline direction, indicating some loss
TABLE I

Effect of sample size on equilibration of $\mathrm{CO}_{2}$ between aspirated sample and mineral oil in quinhydrone microelectrodes

\begin{tabular}{|c|c|c|c|c|}
\hline \multirow{3}{*}{$\begin{array}{l}\mathrm{HCO}_{3}^{-} \\
\text {concen- } \\
\text { tration* }\end{array}$} & \multirow[b]{3}{*}{$\mathrm{PCO}_{2}$} & \multirow{3}{*}{$\begin{array}{l}\mathrm{pH} \text { in } \\
\text { Beckman } \\
\text { electrode }\end{array}$} & \multirow{2}{*}{\multicolumn{2}{|c|}{$\frac{\text { Quinhydrone } \mathrm{pH} \dagger}{\text { Sample size } \ddagger}$}} \\
\hline & & & & \\
\hline & & & $<0.01 \mu \mathrm{l}$ & $>0.05 \mu 1$ \\
\hline$m E q / L$ & $m m H g$ & & & \\
\hline 25 & $\begin{array}{r}38 \\
77 \\
150\end{array}$ & $\begin{array}{l}7.44 \\
7.13 \\
6.84\end{array}$ & $\begin{array}{l}7.43 \\
7.41 \\
7.40\end{array}$ & $\begin{array}{l}7.46 \\
7.17 \\
6.88\end{array}$ \\
\hline 50 & $\begin{array}{r}38 \\
77 \\
150\end{array}$ & $\begin{array}{l}7.74 \\
7.43 \\
7.14\end{array}$ & $\begin{array}{l}7.73 \\
7.74 \\
7.72\end{array}$ & $\begin{array}{l}7.71 \\
7.46 \\
7.18\end{array}$ \\
\hline
\end{tabular}

* Solutions were made isotonic with $\mathrm{NaCl}$.

$\dagger$ Quinhydrone electrodes were filled with mineral oil that had been equilibrated with $\mathrm{CO}_{2}$ tension of $40 \mathrm{~mm} \mathrm{Hg}$.

$\ddagger$ Size of sample aspirated into the quinhydrone electrode

of $\mathrm{CO}_{2}$ into the mineral oil. These results clearly indicate that equilibration of the sample with the $\mathrm{CO}_{2}$ tension of the mineral oil in the quinhydrone electrode is critically dependent upon the size of the sample. To use the quinhydrone electrode as a valid measurement of $\mathrm{HCO}_{3}^{-}$concentration, therefore, it is necessary to limit the sample size to $0.01 \mu 1$ or less. By using this precaution, there was a standard deviation of $\pm 12 \%$ in ten repetitive measurements of the $\mathrm{HCO}_{3}^{-}$concentration in each of the two standards ( 25 and $50 \mathrm{mEq}$ per $\mathrm{L}$ ).

The $\mathrm{pH}$ of blood and urine was measured in a Beckman glass electrode at $37^{\circ} \mathrm{C}$ using a Vibron $\mathrm{pH}$ meter. The $\mathrm{CO}_{2}$ content of plasma was determined with a Natelson microgasometer.

\section{Results}

In initial experiments the intratubular $\mathrm{pH}$ was measured randomly in proximal tubules of nondiuretic rats with the single-barrelled glass $\mathrm{pH}$ electrode and compared to the $\mathrm{pH}$ of proximal tubular fluid measured with quinhydrone $\mathrm{pH}$ electrodes. The average $\mathrm{pH}$ was $6.82 \pm 0.13$ measured with the glass electrode and $6.88 \pm 0.12$ measured with the quinhydrone electrode. Although there was no difference between the two measurements and thus no evidence for a disequilibrium $\mathrm{pH}$ in the proximal tubule, these results can be criticized for two reasons. First, the measurements were not performed simultaneously in the same tubules. Second, in normal rats the concentration of $\mathrm{HCO}_{3}{ }^{-}$in the proximal tubule rapidly falls to low levels $(15,17)$, which subsequently limits the rate of $\mathrm{HCO}_{3}{ }^{-}$reabsorption, thus possibly reducing the rate of $\mathrm{H}_{2} \mathrm{CO}_{3}$ formation. 
To obviate these objections additional studies were performed in which the rats were infused with $\mathrm{NaHCO}_{3}$ to raise the concentration of $\mathrm{HCO}_{3}{ }^{-}$in plasma and glomerular filtrate to a level that would assure maximal rates of $\mathrm{HCO}_{3}{ }^{-}$ reabsorption. Simultaneous measurements of intratubular $\mathrm{pH}$, quinhydrone $\mathrm{pH}$ and blood $\mathrm{pH}$, $\mathrm{CO}_{2}$ content, and $\mathrm{PCO}_{2}$ were obtained. The intratubular $\mathrm{pH}$ measured with the glass electrode could then be compared with the theoretical equilibrium $\mathrm{pH}$ that was calculated from the
$\left[\mathrm{HCO}_{3}{ }^{-}\right]_{\mathrm{TF}}$ and plasma $\mathrm{PCO}_{2}$, assuming the $\mathrm{PCO}_{2}$ of tubular fluid to be equal to the $\mathrm{Pco}_{2}$ of plasma.

Proximal tubule. Table II shows 37 values of intratubular $\mathrm{pH}$ measured with the single-barrelled electrode; 15 measurements obtained with the double-barrelled electrode are listed in Table IV. Most of the rats were alkalotic, with plasma $\mathrm{CO}_{2}$ contents ranging from 19 to $50 \mathrm{mEq}$ per $\mathrm{L}$. As a result of the $\mathrm{NaHCO}_{3}$ infusions and deep anesthesia there were slight to moderate increases in plasma $\mathrm{PCO}_{2}$. The $\mathrm{pH}$ of the fluid measured

TABLE II

Comparison between intratubular $p H$ and calculated equilibrium $p H$ in proximal convoluted tubule during $\mathrm{NaHCO}_{3}$ diuresis*

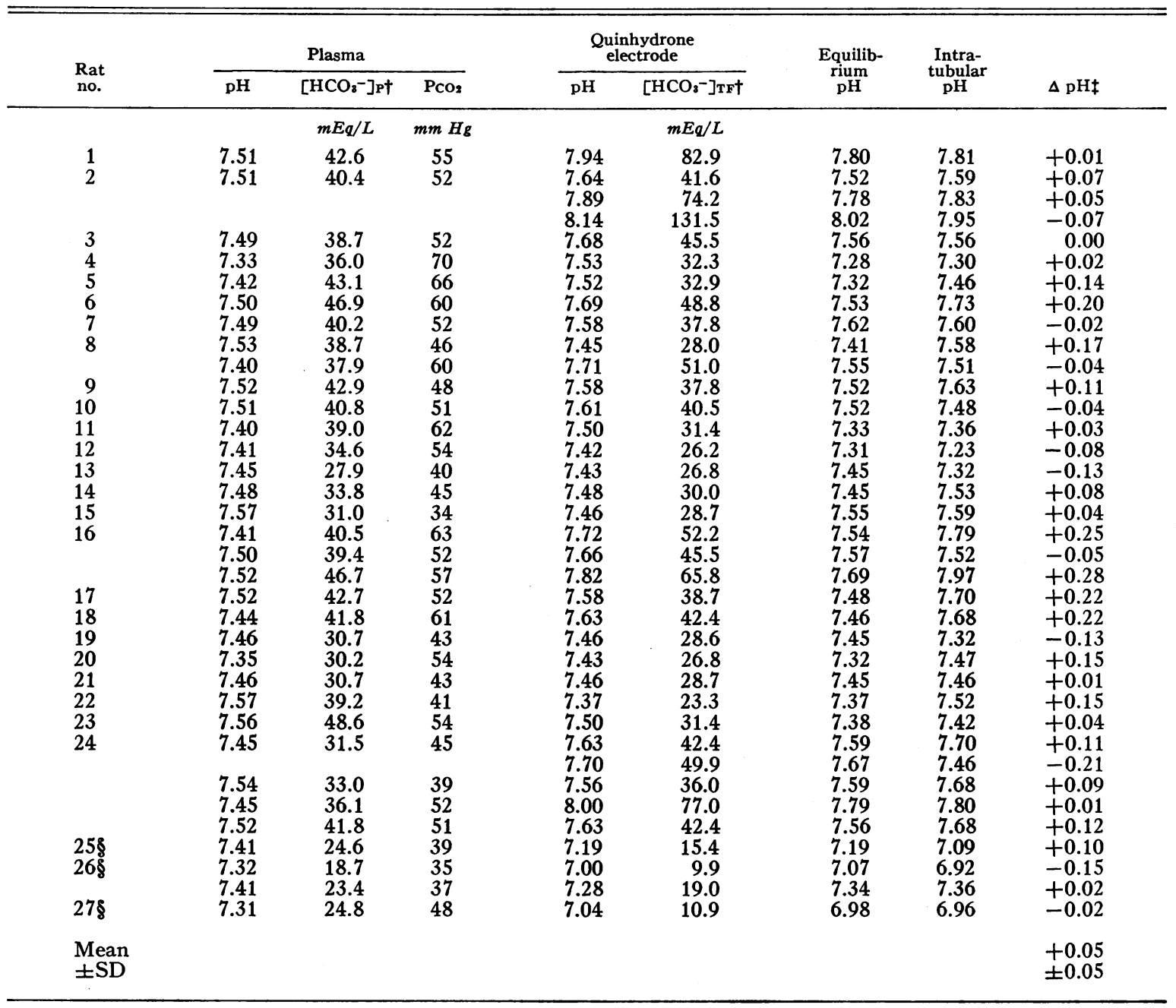

* All measurements of intratubular $\mathrm{pH}$ were made with single-barrelled $\mathrm{pH}$ electrodes.

$+\left[\mathrm{HCO}_{3}-\right] \mathrm{p},\left[\mathrm{HCO}_{3}-\right]_{\mathrm{TF}}=$ the concentration of $\mathrm{HCO}_{3}-$ in plasma and tubular fluid, respectively. $\ddagger \Delta \mathrm{pH}=$ intratubular $\mathrm{pH}-$ equilibrium $\mathrm{pH}$.

$\S \mathrm{NaHCO}_{3}$ not infused. 
TABLE III

Effect of carbonic anhydrase inhibition on intratubular $p H$ in the proximal convoluted tubule

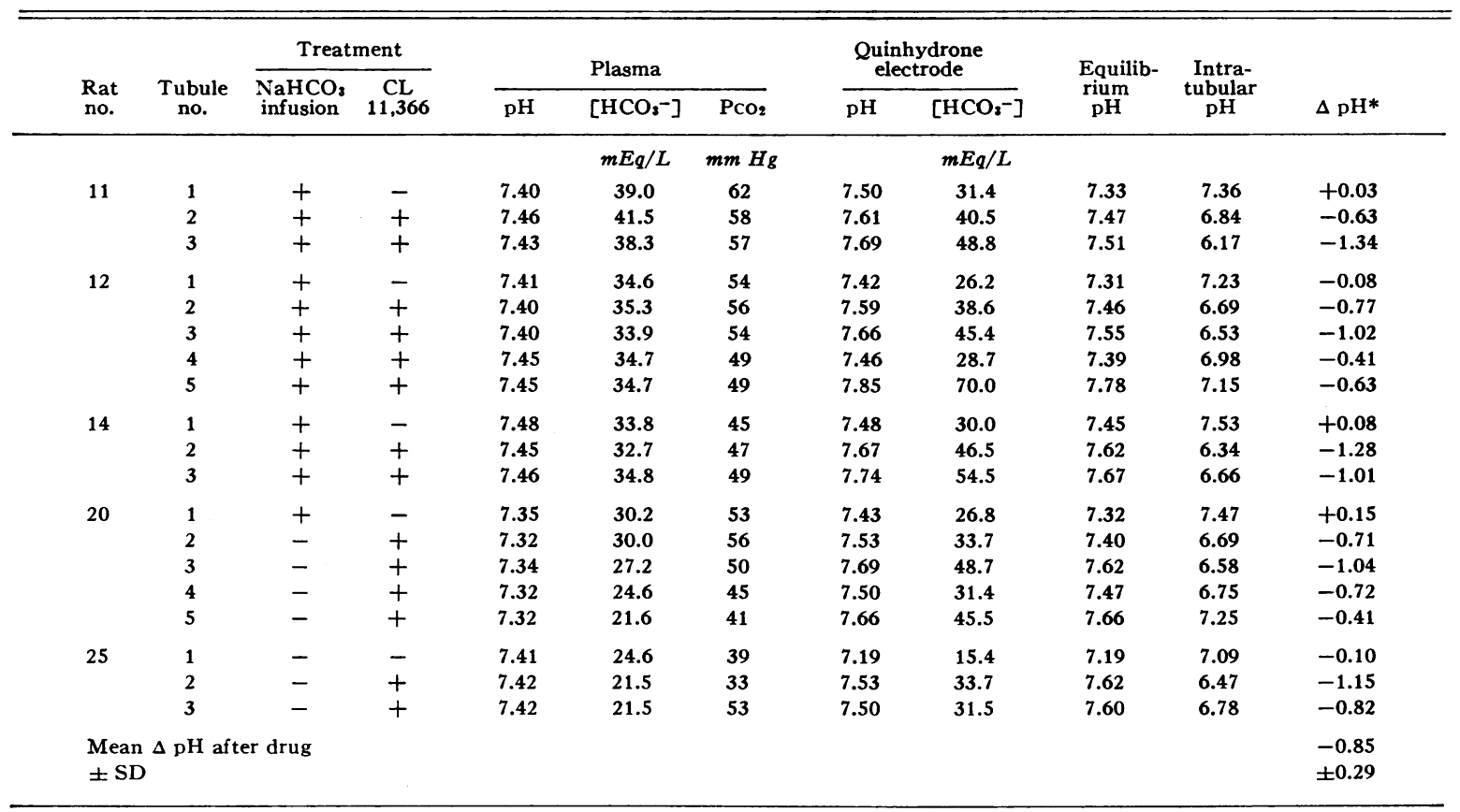

$* \Delta \mathrm{pH}=$ intratubular $\mathrm{pH}-$ equilibrium $\mathrm{pH}$.

with the quinhydrone electrode was, with a few exceptions, either equal to or greater than the $\mathrm{pH}$ of blood.

Despite the wide range in intratubular $\mathrm{pH}$, the agreement between the measured intratubular $\mathrm{pH}$ and the calculated equilibrium $\mathrm{pH}$ in any single tubule was reasonably close. The greatest difference between any two values was $0.28 \mathrm{pH}$ $U$; the average difference was +0.05 with a $\mathrm{SD}$ of \pm 0.05 . In those measurements in which the intratubular $\mathrm{pH}$ was 0.1 or more $\mathrm{pH} \mathrm{U}$ higher than the equilibrium $\mathrm{pH}$, the plasma $\mathrm{PcO}_{2}$ was usually elevated. This finding suggests that in those instances the samples of tubular fluid aspirated into the quinhydrone electrode were too large to permit complete equilibration with the $\mathrm{CO}_{2}$ tension of the mineral oil (Table I). Consequently, the calculated equilibrium $\mathrm{pH}$ would be falsely low and the original $\mathrm{pH}$ measured with the quinhydrone electrode would probably be a more accurate estimate of the true equilibrium $\mathrm{pH}$. There were no significant differences in the values obtained with the single- and double-barrelled glass electrodes, indicating that the proximal transtubular potential was not in- fluencing the measurements with the single-barrelled electrodes.

To investigate the possibility that the catalytic decomposition of $\mathrm{H}_{2} \mathrm{CO}_{3}$ by the action of carbonic anhydrase located in the luminal membrane might be responsible for the absence of a disequilibrium $\mathrm{pH}$, the measurements were performed before and after inhibition of carbonic anhydrase with $2 \mathrm{mg}$ per $\mathrm{kg}$ body weight of CL 11, 366 given intravenously. Table III shows that before administration of the drug the measured intratubular $\mathrm{pH}$, in every instance, approximated the calculated equilibrium $\mathrm{pH}$. However, after carbonic anhydrase was inhibited, the measured intratubular $\mathrm{pH}$ was 0.4 to $1.34 \mathrm{pH} \mathrm{U}$ lower than the calculated equilibrium $\mathrm{pH}$. In rat no. 25 , for example, which was not undergoing $\mathrm{NaHCO}_{3}$ diuresis, carbonic anhydrase inhibition resulted in a rise in the quinhydrone $\mathrm{pH}$ and the calculated equilibrium $\mathrm{pH}$, but a fall in the true intratubular $\mathrm{pH}$.

Distal tubule. A total of 24 measurements of distal intratubular $\mathrm{pH}$ from 17 rats undergoing $\mathrm{NaHCO}_{3}$ diuresis is listed in Table IV. In ten instances measurements of proximal intratubular 
F. C. RECTOR, JR., N. W. CARTER, AND D. W. SELDIN

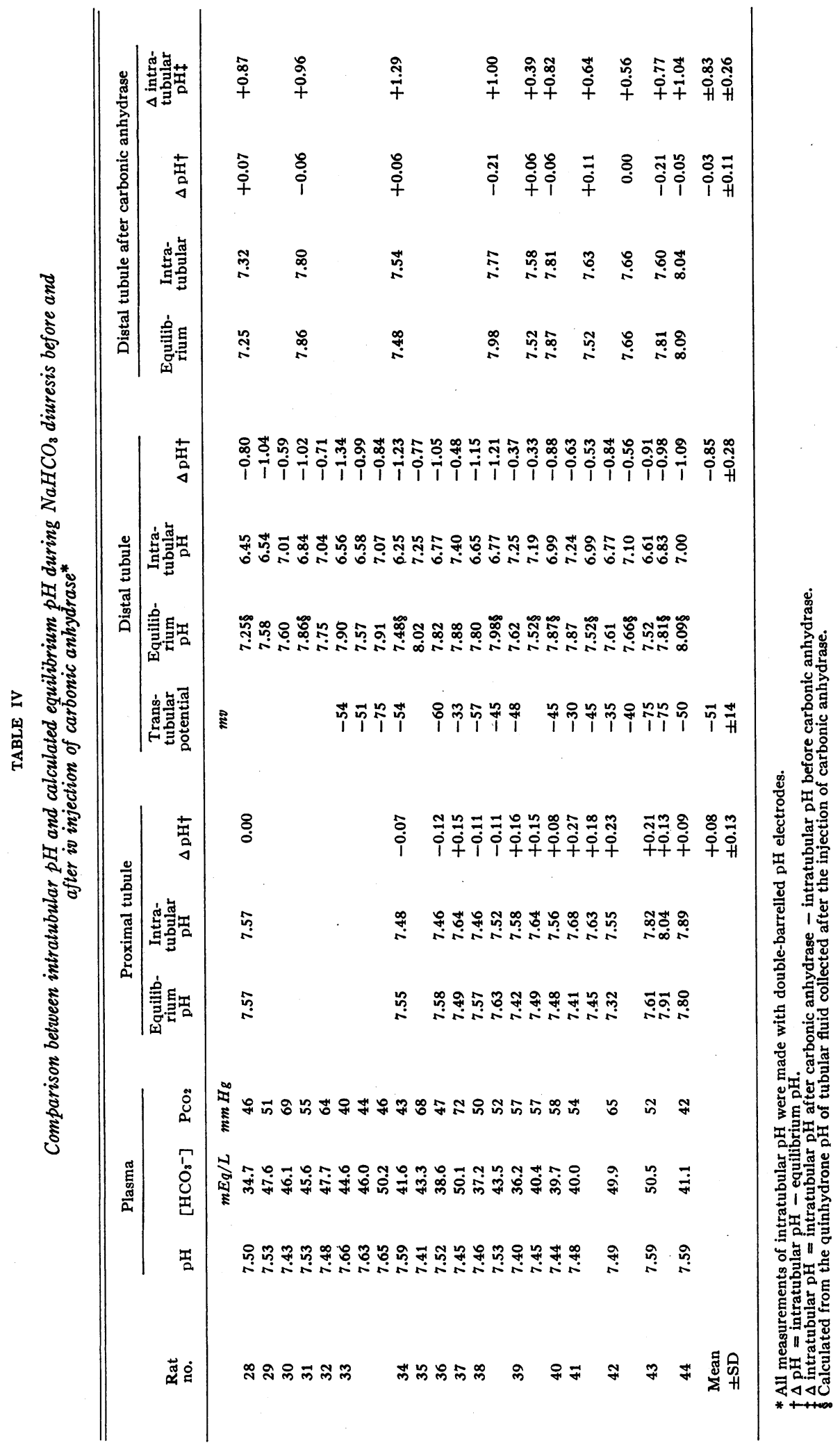


$\mathrm{pH}$ were obtained in the same rat with the same electrode. In every instance the proximal intratubular $\mathrm{pH}$ was very close to the calculated equilibrium $\mathrm{pH}$, whereas in contrast the distal intratubular $\mathrm{pH}$ was always significantly lower than the equilibrium $\mathrm{pH}$, the average difference being $0.85 \mathrm{pH} \mathrm{U}$.

The existence of a disequilibrium $\mathrm{pH}$ in the distal tubule strongly suggests that excess $\mathrm{H}_{2} \mathrm{CO}_{3}$ was being generated and retained in the tubular fluid. To test this possibility more rigorously, the effect of injected carbonic anhydrase on the distal $\mathrm{pH}$ was examined. A distal tubule was punctured and the intratubular $\mathrm{pH}$ continuously recorded; after a stable value was obtained 10 $\mathrm{mg}$ of carbonic anhydrase was injected intravenously. Within 90 seconds there was a rapid shift in $\mathrm{pH}$ in an alkaline direction. This finding was consistently observed in ten experiments; the average $\mathrm{pH}$ change after the injection of carbonic anhydrase was $0.83 \mathrm{pH} \mathrm{U}$ (Table IV). The equilibrium $\mathrm{pH}$ (calculated from the concentration of $\mathrm{HCO}_{3}-$ in samples of tubular fluid collected after injection of carbonic anhydrase) and the intratubular $\mathrm{pH}$ were approximately equal after administration of the enzyme.

The transtubular potential difference across the distal tubule, measured through the reference side of the $\mathrm{pH}$ electrode, ranged from -30 to $-75 \mathrm{mv}$ with the lumen negative relative to the peritubular fluid (Table IV). In general there was a rough but not very impressive correlation between the potential difference (p.d.) and the intratubular $\mathrm{pH}$, the p.d. and the difference between the intratubular $\mathrm{pH}$ and the equilibrium $\mathrm{pH}$, and the p.d. and difference between the intratubular $\mathrm{pH}$ and the blood $\mathrm{pH}$ ( $\mathrm{pH}$ gradient).

\section{Discussion}

Filtered $\mathrm{HCO}_{3}{ }^{-}$is rapidly reabsorbed from both the proximal and distal convoluted tubules (18). If this reabsorptive process were accomplished by $\mathrm{H}^{+}$secretion, the following intratubular reaction would occur:

$$
\begin{aligned}
& \underset{\text { (secreted) }}{\mathrm{H}^{+}}+\underset{\text { (filtered) }}{\mathrm{HCO}_{3}^{-}}
\end{aligned}
$$

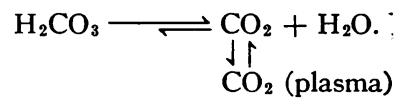

Eventually a steady state would be achieved in which the rate of $\mathrm{H}_{2} \mathrm{CO}_{3}$ removal must equal the rate at which it is generated, which in turn must equal the rate of $\mathrm{HCO}_{3}^{-}$reabsorption. Since the uncatalyzed dehydration of $\mathrm{H}_{2} \mathrm{CO}_{3}$ is not instantaneous, excess $\mathrm{H}_{2} \mathrm{CO}_{3}$ would accumulate in the tubular fluid until the concentration was sufficient to drive the reaction at a rate equal to the over-all reabsorptive rate. At this point the concentration of $\mathrm{H}_{2} \mathrm{CO}_{3}$ would not be in equilibrium with the $\mathrm{CO}_{2}$ tension of the luminal fluid and plasma, and consequently the intratubular $\mathrm{pH}$ would be significantly lower than that calculated from the Henderson-Hasselbalch equation using plasma $\mathrm{PCO}_{2}$ and the luminal concentration of $\mathrm{HCO}_{3}^{-}$.

In the present experiments the intratubular $\mathrm{pH}$ in the proximal tubule was virtually identical to the calculated equilibrium $\mathrm{pH}$ (Table II). This indicates that there was no excess $\mathrm{H}_{2} \mathrm{CO}_{3}$ accumulating in the tubular fluid and that one of the original assumptions was not true. The possibilities raised by these results are as follows: 1) $\mathrm{H}_{2} \mathrm{CO}_{3}$ is rapidly dehydrated under the catalytic impact of carbonic anhydrase located in the luminal surface of the tubular cell ; 2) $\mathrm{H}_{2} \mathrm{CO}_{3}$ is rapidly lost by diffusion out of the lumen $;{ }^{5}$ or 3) $\mathrm{HCO}_{3}{ }^{-}$is not reabsorbed by $\mathrm{H}^{+}$secretion, but rather is removed by some process that does not generate $\mathrm{H}_{2} \mathrm{CO}_{3}$, such as direct transport of $\mathrm{HCO}_{3}{ }^{-}$ions per se.

Inhibition of carbonic anhydrase with the potent inhibitor CL 11, 366 affords a means of determining whether carbonic anhydrase might be exerting a catalytic effect on the luminal fluid. In a previous study (18) it was demonstrated that after maximal inhibition of carbonic anhydrase the rate of $\mathrm{HCO}_{3}-$ reabsorption in the proximal tubule was approximately $40 \%$ of the control rate. Therefore, if $\mathrm{H}^{+}$secretion were the mechanism involved, there still would be significant quantities of $\mathrm{H}_{2} \mathrm{CO}_{3}$ generated, which might accumulate in the tubular fluid because of the virtual absence of renal carbonic anhydrase activity. As shown in Table III, after administration of $\mathrm{CL} 11,366$ the actual intratubular $\mathrm{pH}$

\footnotetext{
5 Although some $\mathrm{H}_{2} \mathrm{CO}_{3}$ may be carried out of the proximal tubule as fluid flows into the loop, the amount is less than one-thousandth of the total $\mathrm{H}_{2} \mathrm{CO}_{3}$ generated and can therefore be ignored.
} 
measured with the glass electrode was $0.85 \mathrm{pH}$ $\mathrm{U}$ lower than the equilibrium $\mathrm{pH}$. Clearly, therefore, $\mathrm{H}_{2} \mathrm{CO}_{3}$ is produced in proximal tubular fluid during the process of $\mathrm{HCO}_{3}{ }^{-}$reabsorption. This proves that $\mathrm{HCO}_{3}{ }^{-}$reabsorption in the proximal tubule is mediated by the secretion of $\mathrm{H}^{+}$. In the uninhibited state, however, carbonic anhydrase has access to luminal fluid, presumably by virtue of its location in the luminal membrane of the cell, thereby rapidly catalyzing the dehydration of the $\mathrm{H}_{2} \mathrm{CO}_{3}$ generated by the reaction between secreted $\mathrm{H}^{+}$and filtered $\mathrm{HCO}_{3}^{-}$. Only after inhibition of carbonic anhydrase does excess $\mathrm{H}_{2} \mathrm{CO}_{3}$ accumulate in the tubular fluid and generate a disequilibrium $\mathrm{pH}$.

Since $\mathrm{H}_{2} \mathrm{CO}_{3}$ is almost instantaneously dehydrated in tubular fluid by the action of carbonic anhydrase, it is probable that little or none of the $\mathrm{H}_{2} \mathrm{CO}_{3}$ is lost by nonionic diffusion out of the lumen. When the enzymatic dehydration is inhibited, however, $\mathrm{H}_{2} \mathrm{CO}_{3}$ accumulates in the tubular fluid, creating a gradient favorable to back diffusion. As suggested previously (6), back diffusion of $\mathrm{H}_{2} \mathrm{CO}_{3}$ from tubular lumen into the cell after inhibition of carbonic anhydrase might play a very important role in sustaining $\mathrm{H}^{+}$ secretion in the face of a diminished intracellular production of $\mathrm{H}^{+}$.

Previous studies from this laboratory (8), in which proximal tubules were perfused with $\mathrm{NaHCO}_{3}$ solutions containing acid-base indicators, gave results indicating that there was a disequilibrium $\mathrm{pH}$ in the uninhibited state, which could be obliterated by adding carbonic anhydrase to the perfusion fluid. On the basis of those results it was concluded that carbonic anhydrase was not located in the luminal membrane of proximal tubular cells. This conclusion is disproved by the present studies. There is, however, a logical explanation for the apparent conflict between these two studies. At least two of the acid-base indicators used in the previous study are known to be inhibitors of carbonic anhydrase (19-21) at concentrations several times smaller than those used in the perfusion solutions (100 $\mathrm{mg}$ per $100 \mathrm{ml}$ ). In view of the results obtained in the present experiments it is reasonable to assume that the indicators inhibited the carbonic anhydrase located in the luminal membrane of the cell, permitting excess $\mathrm{H}_{2} \mathrm{CO}_{3}$ to accumu- late. In the perfusion solutions, containing both the indicators and carbonic anhydrase $(100 \mathrm{mg}$ per $100 \mathrm{ml}$ ), 3 to $10 \%$ of the added enzyme would not be inhibited by the indicator and could thereby catalyze the dehydration of $\mathrm{H}_{2} \mathrm{CO}_{3}$ and obviate the disequilibrium $\mathrm{pH}$. The results of those experiments, therefore, while misleading, are not in serious conflict with the present results.

The distal convoluted tubule, in contrast to the proximal tubule, always exhibited a marked disequilibrium $\mathrm{pH}$ even when carbonic anhydrase was uninhibited. In rats undergoing $\mathrm{NaHCO}_{3}$ diuresis with an intact carbonic anhydrase enzyme system the distal intratubular $\mathrm{pH}$ was 0.85 $\mathrm{U}$ below the calculated equilibrium $\mathrm{pH}$ (Table IV). The obliteration of this difference between the intratubular $\mathrm{pH}$ and the equilibrium $\mathrm{pH}$ by the intravenous injection of carbonic anhydrase (Figure 2 and Table IV) proves that the $\mathrm{pH}$ difference was due to excess $\mathrm{H}_{2} \mathrm{CO}_{3}$. The accumulation of excess $\mathrm{H}_{2} \mathrm{CO}_{3}$ in distal tubular fluid indicates, first, that distal, as well as proximal, $\mathrm{HCO}_{3}^{-}$reabsorption is mediated by $\mathrm{H}^{+}$ secretion; and second, that in the distal tubule, in contrast to the proximal tubule, carbonic anhydrase is not located in the luminal membrane of the tubular cells.

The finding of a disequilibrium $\mathrm{pH}$ in the distal tubule lends strong support to the hypothesis of Pitts and Lotspeich (22) that the high $\mathrm{CO}_{2}$ tensions of alkaline urines are the consequence of $\mathrm{H}^{+}$secretion in the distal portion of the nephron, with subsequent delayed dehydration of the $\mathrm{H}_{2} \mathrm{CO}_{3}$ generated by this process. Although the present experiments indicate that this, in fact, is the primary mechanism for the high $\mathrm{CO}_{2}$ tensions, the concentration of excess $\mathrm{H}_{2} \mathrm{CO}_{3}$ (approximately $0.01 \mathrm{mM}$ ), calculated from the observed disequilibrium $\mathrm{pH}$, would be sufficient to raise the urinary $\mathrm{PCO}_{2}$ by only $0.5 \mathrm{~mm} \mathrm{Hg}$. It is clear, therefore, that other factors play a critical role in generating the high urinary $\mathrm{CO}_{2}$ tensions. On the basis of the marked influence of the buffer content of the urine on urinary $\mathrm{CO}_{2}$ tensions, Kennedy, Eden, and Berliner (23) have suggested that, as excess $\mathrm{H}_{2} \mathrm{CO}_{3}$ is dehydrated, $\mathrm{H}^{+}$is liberated from urinary buffers to form additional $\mathrm{H}_{2} \mathrm{CO}_{3}$ (and eventually $\mathrm{CO}_{2}$ ). Rector, Portwood, and Seldin (24), however, in human studies found high $\mathrm{CO}_{2}$ tensions in urines con- 
taining only minimal quantities of buffer. Upon re-examining their published urinary buffer titration curves (24), it is apparent that a disequilibrium $\mathrm{pH}$ of 1.5 to 2.0 would be required to generate the observed urinary $\mathrm{CO}_{2}$ tensions. Since disequilibrium $\mathrm{pH}$ of this magnitude was not observed in the present study in rats, the possibility that medullary trapping of $\mathrm{CO}_{2}$ released in the collecting duct might also contribute to the final $\mathrm{CO}_{2}$ tension of the urine must be considered (25). The precise contribution of the countercurrent system to urinary $\mathrm{PCO}_{2}$, however, can be assessed only after carefully examining the relation between the distal disequilibrium $\mathrm{pH}$, the buffer content of the urine, and urine $\mathrm{PCO}_{2}$ in the same animal.

The present experiments provide strong direct proof that $\mathrm{H}^{+}$secretion accounts for $\mathrm{HCO}_{3}{ }^{-}$reabsorption in both the proximal and distal portions of the nephron. Although the data in these studies are not sufficiently precise to exclude the possibility that some $\mathrm{HCO}_{3}{ }^{-}$is reabsorbed directly without reacting with $\mathrm{H}^{+}$, possibly by passive diffusion along the favorable electrochemical gradient across the tubular epithelium, the magnitude of the disequilibrium $\mathrm{pH}$ in both the proximal tubule after carbonic anhydrase inhibition and the distal tubule suggests that $\mathrm{H}^{+}$secretion is by far the predominant mechanism involved. This is consistent with the previous finding that virtually all $\mathrm{HCO}_{3}{ }^{-}$reabsorption is dependent upon either $\mathrm{PCO}_{2}$ or carbonic anhydrase (6). Thus, $\mathrm{H}^{+}$secretion appears to account for almost all $\mathrm{HCO}_{3}{ }^{-}$reabsorption. The precise details of the $\mathrm{H}^{+}$secretory mechanism, however, appear to differ in the proximal and distal tubules, particularly with respect to the role of carbonic anhydrase.

Analyses of isolated tubules by Kark and his colleagues (26) for carbonic anhydrase activity, as well as histochemical stains for enzyme activity (27), have shown the enzyme to be present in both proximal and distal portions of the nephron. The histochemical staining, however, which is dependent on the precipitation of $\mathrm{CoCO}_{3}$ at sites of enzymatic activity, with subsequent conversion to $\mathrm{CoS}$, gives different patterns in proximal and distal tubules (27). In the proximal tubule there is dense localization of enzyme along the peritubular membrane with less intense activity throughout the remainder of the cellular cytoplasm; in addition, there is precipitation of $\mathrm{CoS}$ in the tubular lumen, suggesting that the tubular fluid is exposed to enzymatic activity. In contrast, the distal tubule shows only diffuse activity throughout the cell cytoplasm without the dense localization along the peritubular surface and, more importantly, without precipitate in the tubular lumen. These histochemical studies, while open to criticism concerning the specificity of the measurements, are consistent with the findings in the present study which indicate that luminal fluid is exposed to carbonic anhydrase activity in the proximal but not in the distal tubule.

According to current concepts the principal function of carbonic anhydrase is to provide a plentiful supply of $\mathrm{H}^{+}$for the secretory process by catalyzing the hydration of $\mathrm{CO}_{2}$ to form $\mathrm{H}_{2} \mathrm{CO}_{3}$ in the tubular cells. ${ }^{6}$ It is apparent from the present studies that a second and equally important role is subserved by carbonic anhydrase in the proximal tubule. By virtue of its location in the luminal membrane and its contact with tubular fluid, the $\mathrm{H}_{2} \mathrm{CO}_{3}$, formed by the reaction of secreted $\mathrm{H}^{+}$with filtered $\mathrm{HCO}_{3}^{-}$, is rapidly broken down; consequently the steady-state intratubular $\mathrm{pH}$ is approximately 1 to $1.5 \mathrm{pH} \mathrm{U}$ higher than it would be if carbonic anhydrase were not acting on the tubular fluid. Carbonic anhydrase, therefore, by catalyzing the decomposition of $\mathrm{H}_{2} \mathrm{CO}_{3}$, decreases by approximately 20 -fold the concentration gradient against which $\mathrm{H}^{+}$is secreted. In effect this reduces the energy required to transport $\mathrm{H}^{+}$by approximately 2,000 calories per equivalent $\mathrm{H}^{+}$secreted. $^{7}$ Thus, carbonic anhydrase facilitates the transport of large quantities of $\mathrm{H}^{+}$in the proximal tubule by both furnishing a supply of $\mathrm{H}^{+}$and preventing the generation of steep $\mathrm{pH}$ gradients.

\footnotetext{
6 An alternative view (28) is that, in the process of secreting $\mathrm{H}^{+}$into the lumen, $\mathrm{H}_{2} \mathrm{O}$ is split, leaving the residual $\mathrm{OH}^{-}$in the cell; the role of the $\mathrm{H}_{2} \mathrm{CO}_{3}$ in this schema is to neutralize the $\mathrm{OH}^{-}$rather than to serve as a source of $\mathrm{H}^{+}$.

7 The calculated energy required for transtubular sodium transport is approximately 500 calories per equivalent transported. It is obvious, therefore, that luminal carbonic anhydrase, by dissipating $\mathrm{pH}$ gradients, effects a major conservation of energy in the process of $\mathrm{H}^{+}$ secretion.
} 
The presence or absence of luminal carbonic anhydrase probably determines, to a large extent, the transport characteristics of the $\mathrm{H}^{+}$secretory system. In the presence of an intact carbonic anhydrase enzyme system, the secretion of $\mathrm{H}^{+}$in the proximal tubule is probably limited by $\mathrm{pH}$ gradients only when the concentration of $\mathrm{HCO}_{3}{ }^{-}$in tubular fluid falls below a certain level; above this level the $\mathrm{pH}$ of the tubular fluid is sufficiently alkaline to assure maximal rates of $\mathrm{H}^{+}$secretion. Consequently, raising the concentration of $\mathrm{HCO}_{3}^{-}$has no further effect on the rate of $\mathrm{HCO}_{3}{ }^{-}$reabsorption. In the distal tubule, in contrast, there is no luminal carbonic anhydrase, and the tubular fluid is relatively acid even in the presence of high $\mathrm{HCO}_{3}^{-}$concentrations (Table IV). For this reason $\mathrm{H}^{+}$secretion in the distal tubule may be partially gradient limited over the full range of $\mathrm{HCO}_{3}-$ concentrations and may never achieve its full secretory capacity. The reason that the peculiar behavior of the distal $\mathrm{H}^{+}$secretory system is not reflected in a progressively rising total $\mathrm{HCO}_{3}{ }^{-}$reabsorptive capacity as serum $\mathrm{HCO}_{3}{ }^{-}$is progressively elevated is most likely because the distal tubule probably accounts for no more than 10 to $15 \%$ of the total $\mathrm{HCO}_{3}{ }^{-}$reabsorptive capacity (18).

Inhibition of carbonic anhydrase appears to depress $\mathrm{HCO}_{3}{ }^{-}$reabsorption in two ways: first, by decreasing the supply of $\mathrm{H}^{+}$along the entire nephron; second, by permitting $\mathrm{H}_{2} \mathrm{CO}_{3}$ to accumulate in proximal tubular fluid and thus generate $\mathrm{pH}$ gradients. Since inhibition of carbonic anhydrase depresses $\mathrm{HCO}_{3}{ }^{-}$reabsorption only very slightly in the distal tubule, but by $60 \%$ in the proximal tubule (18), apparently the development of $\mathrm{pH}$ gradient plays the major role in the inhibitory process [it is of interest that before inhibition of carbonic anhydrase proximal $\mathrm{HCO}_{3}{ }^{-}$ reabsorption was approximately 2.5 times greater than the distal rate, but after inhibtion proximal and distal reabsorption were approximately equal (18)]. Inhibition of carbonic anhydrase, therefore, probably makes the $\mathrm{H}^{+}$secretory process along the entire nephron gradient limited. As a result, $\mathrm{H}^{+}$secretion in the proximal tubule would reach a limiting gradient and stop despite the presence of significant concentrations of $\mathrm{HCO}_{3}{ }^{-}$in the tubular fluid; excessive $\mathrm{HCO}_{3}{ }^{-}$ would therefore be delivered to the distal tubule, and some $\mathrm{HCO}_{3}{ }^{-}$would spill into the urine even in the presence of a severe metabolic acidosis (6, 29). Moreover, because of the gradient limitation, the maximal rate of $\mathrm{HCO}_{3}^{-}$reabsorption would not be reached even with very high $\mathrm{HCO}_{3}^{-}$ concentrations. The net effect would be a reduction in the maximal reabsorptive capacity and a marked spillage of $\mathrm{HCO}_{3}$ - at low concentrations. This would explain the marked splaying of the $\mathrm{HCO}_{3}{ }^{-}$titration curves after inhibition of carbonic anhydrase observed by Schwartz, Falbriard, and Relman (29) and by Rector and associates (6).

Several investigators have suggested the possibility that $\mathrm{H}^{+}$secretion, at least in the proximal tubule, might be a passive process driven by the transtubular potential difference $(30,31)$. In support of this hypothesis Bank (31) found a rough correlation between the transtubular potential and the minimal $\mathrm{pH}$ established in the proximal tubules, under conditions where the rates of $\mathrm{H}^{+}$secretion were probably very small. In the present studies steep $\mathrm{pH}$ gradients between tubular fluid and blood developed after inhibition of carbonic anhydrase (Table III). To account for $\mathrm{pH}$ gradients of this magnitude the proximal transtubular potential ${ }^{8}$ would have to average 46 $\mathrm{mv}$ (range from 30 to $80 \mathrm{mv}$ ), assuming the system to be at equilibrium, i.e., no net $\mathrm{H}^{+}$movement. However, under these experimental conditions there was considerable $\mathrm{H}^{+}$secretion; therefore, the system was not at equilibrium. Consequently, the potential would have to be much higher than $46 \mathrm{mv}$ to account for the $\mathrm{H}^{+}$ secretion during carbonic anhydrase inhibition. Malnic, Klose, and Giebisch (32), however, found the proximal potential to be unchanged after inhibition of carbonic anhydrase, averaging -25 mv. The steep $\mathrm{pH}$ gradients after carbonic anhydrase inhibition, therefore, strongly suggest that in the proximal tubule there is an active transport process capable of secreting $\mathrm{H}^{+}$against an electrochemical gradient.

In the distal tubule the transtubular potentials are much higher (33) and are sufficient to account for the minimal $\mathrm{pH}$ values achieved under

8 If the distribution of $\mathrm{H}^{+}$across the tubule is strictly passive, the relation between the transtubular potential $\left(\mathrm{E}_{\mathrm{r}}\right)$ and the $\mathrm{pH}$ gradient at equilibrium is given by the Nernst equation: $E_{T}=-61 \mathrm{mv}\left(\mathrm{pH}_{\mathrm{blood}}-\mathrm{pH}_{\mathrm{TF}}\right)$. 
conditions where the rate of net secretion is very small (34). In the present studies the distal transtubular potentials averaged $-51 \mathrm{mv}$, ranging from -30 to $-75 \mathrm{mv}$ (Table IV). The measured $\mathrm{pH}$ gradients between blood and tubule averaged $0.65 \mathrm{pH} \mathrm{U}$ (Table IV). In most instances the potentials were sufficient to generate the observed $\mathrm{pH}$ gradients, providing there was little or no net movement of $\mathrm{H}^{+}$. During $\mathrm{NaHCO}_{3}$ diuresis, however, the net movement of $\mathrm{H}^{+}$should have been at a maximal level. Although these experiments did not demonstrate the movement of $\mathrm{H}^{+}$against electrochemical gradients, it is unlikely that the observed transtubular potentials could drive the secretion of $\mathrm{H}^{+}$at maximal rates against an average gradient of $0.65 \mathrm{pH}$ U. The distal secretion of $\mathrm{H}^{+}$, therefore, is probably also an active transport process.

\section{Summary}

The mechanism of $\mathrm{HCO}_{3}{ }^{-}$reabsorption in proximal and distal tubules was examined in rats undergoing $\mathrm{NaHCO}_{3}$ diuresis. The steady-state intratubular $\mathrm{pH}$ was measured with $\mathrm{pH}$-sensitive glass microelectrodes and compared with the equilibrium $\mathrm{pH}$ calculated from the $\mathrm{HCO}_{3}^{-}$concentration of the tubular fluid (measured with quinhydrone electrodes) and plasma $\mathrm{PCO}_{2}$.

In the proximal tubule the intratubular $\mathrm{pH}$ and the equilibrium $\mathrm{pH}$ were identical, indicating no accumulation of excess $\mathrm{H}_{2} \mathrm{CO}_{3}$. After inhibition of carbonic anhydrase, however, intratubular $\mathrm{pH}$ was significantly lower $(0.85 \mathrm{pH} \mathrm{U})$ than the equilibrium $\mathrm{pH}$. It was concluded that $\mathrm{HCO}_{3}{ }^{-}$reabsorption in the proximal tubule was mediated by $\mathrm{H}^{+}$secretion, but that carbonic anhydrase located in the luminal membrane of the cell prevented $\mathrm{H}_{2} \mathrm{CO}_{3}$ from accumulating in the tubular fluid.

In the distal tubule the intratubular $\mathrm{pH}$ was $0.85 \mathrm{U}$ lower than the equilibrium $\mathrm{pH}$. This difference could be obliterated by an intravenous injection of carbonic anhydrase. It was concluded that $\mathrm{HCO}_{3}{ }^{-}$reabsorption in this segment was also accomplished by $\mathrm{H}^{+}$secretion. The accumulation of excess $\mathrm{H}_{2} \mathrm{CO}_{3}$ in the tubular fluid indicated that, in contrast to the proximal tubule, carbonic anhydrase was not located in the luminal membrane of distal tubular cells.

\section{References}

1. Pitts, R. F., and R. S. Alexander. The nature of the renal tubular mechanism for acidifying the urine. Amer. J. Physiol. 1945, 144, 239.

2. Berliner, R. W. Renal secretion of potassium and hydrogen ions. Fed. Proc. 1952, 11, 695.

3. Brazeau, P., and A. Gilman. Effect of plasma $\mathrm{CO}_{2}$ tension on renal tubular reabsorption of bicarbonate. Amer. J. Physiol. 1953, 175, 33.

4. Relman, A. S., B. Etsten, and W. B. Schwartz. The regulation of renal bicarbonate reabsorption by plasma carbon dioxide tension. J. clin. Invest. 1953, 32, 972.

5. Dorman, P. J., W. J. Sullivan, and R. F. Pitts. The renal response to acute respiratory acidosis. J. clin. Invest. 1954, 33, 82.

6. Rector, F. C., Jr., D. W. Seldin, A. D. Roberts, Jr., and J. S. Smith. The role of plasma $\mathrm{CO}_{2}$ tension and carbonic anhydrase activity in the renal reabsorption of bicarbonate. J. clin. Invest. 1960, 39, 1706.

7. Walser, M., and G. H. Mudge. Renal excretory mechanisms in Mineral Metabolism, C. L. Comar and F. Bronner, Eds. New York, Academic Press, 1960 , p. 288.

8. Rector, F. C., Jr., and N. W. Carter. Evidence for a disequilibrium $\mathrm{pH}$ in the proximal tubule of rat kidney. Proc. Soc. exp. Biol. (N. Y.) 1963, 112, 466.

9. Bank, N., and H. S. Aynedjian. Measurements of tubular fluid $\mathrm{pH}$ in vivo in rats. Nature (Lond.) 1963, 197, 185.

10. Menaker, W. Buffer equilibria and reabsorption in the production of urinary acidity. Amer. J. Physiol. 1948, 154, 174.

11. Travis, D. M., C. Wiley, B. R. Nechay, and T. H. Maren. Selective renal carbonic anhydrase inhibition without respiratory effect : pharmacology of 2-benzenesulfonamido-1,3,4-thiadiazole-5-sulfonamide (CL 11,366). J. Pharmacol. exp. Ther. 1964, 143, 383.

12. Davis, R. P. The kinetics of the reaction of human erythrocyte carbonic anhydrase. I. Basic mechanism and the effect of electrolytes on enzyme activity. J. Amer. chem. Soc. 1958, 80, 5209.

13. Bloomer, H. A., F. C. Rector, Jr., and D. W. Seldin. The mechanism of potassium reabsorption in the proximal tubule of the rat. J. clin. Invest. 1963, 42, 277.

14. Pierce, J. A., and H. Montgomery. A microquinhydrone electrode: its application to the determination of the $\mathrm{pH}$ of glomerular urine of Necturus. J. biol. Chem. 1935, 110, 763.

15. Rector, F. C., Jr., H. A. Bloomer, and D. W. Seldin. Effect of potassium deficiency on the reabsorption of bicarbonate in the proximal tubule of the rat kidney. J. clin. Invest. 1964, 43, 1976. 
16. Clapp, J. R., J. F. Watson, and R. W. Berliner. Osmolality, bicarbonate concentration, and water reabsorption in the proximal tubule of the dog nephron. Amer. J. Physiol. 1963, 205, 273.

17. Gottschalk, C. W., W. E. Lassiter, and M. Mylle. Localization of urine acidification in the mammalian kidney. Amer. J. Physiol. 1960, 198, 581.

18. Rector, F. C., Jr. Micropuncture studies on the mechanism of urinary acidification in Proceedings, Fifteenth Annual Conference on the Kidney, J. Metcoff, Ed. Boston, Little, Brown, in press.

19. Roughton, F. J. W., and A. M. Clark. Carbonic anhydrase in The Enzymes, J. B. Sumner and K. Myrbäck, Eds. New York, Academic Press, 1951, vol. 1, part 2, pp. 1250-1265.

20. Kiese, M., and A. B. Hastings. Factors affecting the activity of carbonic anhydrase. J. biol. Chem. 1940, 132, 281.

21. Wilbur, K. M., and N. G. Anderson. Electrometric and colormetric determination of carbonic anhydrase. J. biol. Chem. 1948, 176, 147.

22. Pitts, R. F., and W. D. Lotspeich. Bicarbonate and the renal regulation of acid base balance. Amer. J. Physiol. 1946, 147, 138.

23. Kennedy, T. J., Jr., M. Eden, and R. W. Berliner. Interpretation of urine $\mathrm{CO}_{2}$ tension. Fed. Proc. 1957, 16, 72.

24. Rector, F. C., Jr., R. M. Portwood, and D. W. Seldin. Examination of the mixing hypothesis as an explanation for elevated urinary $\mathrm{CO}_{2}$ tensions. Amer. J. Physiol. 1959, 197, 861.

25. Ullrich, K. J., K. Kramer, and J. W. Boylan. Present. knowledge of the counter-current system in the mammalian kidney in Heart, Kidney and
Electrolytes, C. K. Friedberg, Ed. New York, Grune \& Stratton, 1962, p. 1.

26. Kark, R. M., H. Mattenheimer, S. L. Bonting, V. E. Pollak, and R. C. Muehrcke. Quantitative histochemistry of the nephron in Ciba Foundation Symposium on Renal Biopsy: Clinical and Pathological Significance, G. E. W. Wolstenholme and M. P. Cameron, Eds. Boston, Little, Brown, 1961, p. 309.

27. Hausler, G. Zur Technik und Spezifität des histochemischen Carboanhydrasenachweises im Modellversuch und in Gewebsschnitten von Rattennieren. Z. Zellforsch. Abt. Histochem. 1958, 1, 29.

28. Berliner, R. W. Outline of renal physiology in Diseases of the Kidney, M. B. Strauss and L. G. Welt, Eds. Boston, Little, Brown, 1963, p. 30.

29. Scwartz, W. B., A. Falbriard, and A. S. Relman. An analysis of bicarbonate reabsorption during partial inhibition of carbonic anhydrase. J. clin. Invest. 1958, 37, 744.

30. Pitts, R. F. Some reflections on mechanisms of action of diuretics. Amer. J. Med. 1958, 24, 745.

31. Bank, N. Relationship between electrical and hydrogen ion gradients across rat proximal tubule. Amer. J. Physiol. 1962, 203, 577.

32. Malnic, G., R. M. Klose, and G. Giebisch. Micropuncture study of renal potassium excretion in the rat. Amer. J. Physiol. 1964, 206, 674.

33. Clapp, J. R., F. C. Rector, Jr., and D. W. Seldin. Effect of unreabsorbed anions on proximal and distal transtubular potentials in rats. Amer. J. Physiol. 1962, 202, 781.

34. Bloomer, H. A., F. C. Rector, Jr., and D. W. Seldin. Unpublished observations. 